\title{
Influence of Water Aging on Microtensile Bond Strength of a Flowable and a Packable Bulk-fill Resin Composites to Dentin
}

\author{
Ayah Atif Selim ${ }^{1 *}$, Ahmed Fawzy Abo Elezz ${ }^{2}$, Rehab Khalil Safy ${ }^{2}$ \\ ${ }^{1}$ Department of Restorative Dentistry, Faculty of Dentistry, Horus University, Egypt; ${ }^{2}$ Department of Restorative Dentistry, \\ Faculty of Dentistry, Suez Canal University, Egypt
}

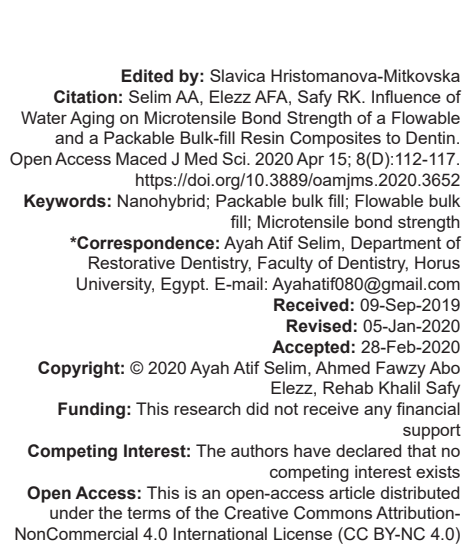

\section{Introduction}

Early since the first report 1960s [1], resin composites (RCs) become increasingly popular day by day in dentistry. RCs were used for many reasons. Some challenges have appeared together with their clinical application, as polymerization shrinkage, absence of cavity wall adaptation, microleakage with subsequent secondary caries, restoration loss, inflammation of pulp, sensitivity postoperatively, micro or macro cracks in both RCs, and surface of the tooth [2], [3]. Manufacturers tried to enhance RC materials' physical and mechanical properties to overcome these problems. Furthermore, many methods and many innovations have been presented such as incremental layering, changes in curing modes, add an intermediate layer to reduce the polymerization shrinkage, and provide a tight marginal seal [1], [3], [4], [5]. Among these, the most common accepted technique is incremental layering [6]. This procedure, however, has some drawbacks includes the option of inclusion of voids, contamination between layers, bonding failures, and the time required for each layer to be placed and polymerized, instead of supplying the resin with a single bulk layer [6], [7], [8].

Researches on minimizing the stresses of polymerization shrinkage presented a new class of restorative material called "bulk fill materials." Therefore, bulk filling techniques have become more widely used following the development of materials with better curing [9], [10] and controlled polymerization contraction stresses [11], [12]. Unlike the maximum recommended increments with $2 \mathrm{~mm}$ in thickness for conventional RCs, manufacturers recommend increments with 4 or $5 \mathrm{~mm}$ for the bulk-fill RCs. There is no doubt that using bulk filling method simplifies the restoration process and saves clinical time in deep and wide cavities [13]. This simpler strategy is related to enhanced composite translucency, permitting increased light transmission with depth, and more reactive photoinitiators to be added [14], [15]. In addition, these materials are claimed to have low shrinkage stress due to inclusion of proprietary stress reliever molecules and polymerization modulators [14], [16]. Bulk-fill RCs presently on the market are either flowable bulkfill RCs designed to be used as a base material with decreased polymerization contraction stress [1], [17] 
or packable bulk-fill RCs designed to restore the entire body of the restoration [18]. Limited numbers of studies comparing the flowable bulk fill, packable bulk fill and incrementally applied nanohybrid RC are available. So that the present study was designed to investigate the microtensile bond strength ( $\mu$ TBS) of a flowable and a packable bulk-fill RCs to human dentin compared to that of an incrementally applied nanohybrid $\mathrm{RC}$ one.

\section{Materials and Methods}

\section{Specimen preparation}

A total of 45 intact, sound, freshly human impacted third molars extracted from patients aged 20-30 years old were collected to prepare the specimens for the $\mu$ TBS testing [19]. Teeth were used with approval from the Research Ethics Committee of Faculty of Dentistry, Suez Canal University, Egypt (number 16/2017). All the teeth exhibiting any signs of caries, microcracks, or any other defective structure were discarded [20]. Then, the teeth were stored in distilled water having $0.5 \%$ chloramine-T antiseptic solution at room temperature until being utilized [19], [21]. A cylindrical Teflon mold (15-mm diameter and 40-mm height) was used to produce acrylic resin blocks. Screws were used to hold the tooth in place parallel to the long axis of the mold, during the setting of acrylic resin. Teeth fixed in blocks of acrylic resin were then mounted in an automated diamond saw (Isomet 4000, Buehler Ltd., Lake Bluff, USA) [21], which was used for all sectioning procedures in this study. The occlusal enamel of teeth was removed perpendicular to the long axis of teeth, to expose flat dentin surface at a standardized depth [22]. The superficial depth of dentin was reached by the removal of occlusal enamel of the teeth till the central fossa forming a flat surface, then with a size 2 (ADA size number) round carbide bur (DIA TESSIN, Switzerland) mounted in the automated diamond saw an indentation of $1 \mathrm{~mm}$ depth in dentin was prepared. The depth of indentation was guided using a rubber stopper mounted to the shaft of the round bur [19]. The final depth was reached by removal of the occlusal surface with the same automated diamond saw under continuous water coolant till the indention disappears [19], [22]. Exposed dentin surfaces were further polished for removal of any debris. Teeth were randomly divided into three groups (C) according to type of RC material $(n=15)$ which had been used for restoring the teeth. Where nanohybrid RC (Grandio ${ }^{\circledR} \mathrm{SO}$ ) was used as the control group (C1), packable bulk-fill RC (X-tra fil ${ }^{\circledR}$ ) was used for restoring teeth in $\mathrm{C} 2$ group and flowable bulk-fill $\mathrm{RC}$ (X-tra base ${ }^{\circledR}$ ) was used for restoring teeth in C3 group. For restoration of teeth, the prepared occlusal surface of each tooth was surrounded with a metal matrix band (Tofflemire Matrix Bands; Produits Dentaires SA,
Vevey, Switzerland). The occlusal surface of each tooth was then acid etched for $10 \mathrm{~s}$, washed thoroughly with water and dried gently with air jets before application of bonding system (Solobond $\mathrm{M}^{\circledR}$ ) where both were applied according to manufacturer's instructions [23]. For all teeth RC was packed on the occlusal surface within the metal matrix band up to $(7 \mathrm{~mm}$ length, $5 \mathrm{~mm}$ width, and $4 \mathrm{~mm}$ height) using a digital caliper (Mitutoyo, Japan) to ensure sufficient bulk for the $\mu$ TBS test. For both types of bulk-fill RC, they were packed as one increment and cured for $10 \mathrm{~s}$ according to manufacturer's instructions. While the incrementally applied nanohybrid RC was packed in two horizontal increments each one with $2 \mathrm{~mm}$ thickness and cured for $10 \mathrm{~s}$ according to manufacturer's instructions. The RC was light cured using a $1200 \mathrm{~mW} / \mathrm{cm}^{2}$ light-emitting diode light curing unit (Elipar S10). Each group was further subdivided into three subgroups $(n=5)$ according to the water storage time, where in subgroup 1 ; teeth were stored for $24 \mathrm{~h}$ (T1), subgroup 2; teeth were stored for 3 months (T2), while for subgroup 3; and teeth were stored for 6 months (T3). Teeth of each subgroup were stored separately in distilled water at room temperature in a light tightlysealed plastic container, labeled according to treatment and time of storage. Materials that have been used in this study are shown in Table 1.

\section{Beams preparation}

After mounting in the gripping attachment, each prepared specimen was serially sectioned perpendicular to the bonded interface. Serial sectioning was done in buccolingual direction then in mesiodistal direction using a $0.3-\mathrm{mm}$ thick diamond coated disc (Buehler, USA) under copious coolant [21], [23]. The peripheral beams were executed and only the central beams from each specimen were selected in order to eliminate substrate regional variability [24]. Each beam was composed of composite and dentin with adhesive at the interface. The resultant beams were $0.9 \pm 0.1 \mathrm{~mm}$ in thickness and $7 \pm 1 \mathrm{~mm}$ in length. A digital caliper was used to check the thickness and length of all beams [19], [21], [23].

\section{$\mu$ TBS measurement}

Five beams from each specimen were selected for the $\mu$ TBS measurement. In the central groove of the jig, each beam was aligned with and glued in place by its end using cyanoacrylate-based glue (Zapit, DVA, Zapit; Dental Ventures of America, Corona, CA, USA) [24], [25]. Geraldeli's jig was used to mount beams into the universal testing machine (Instron, Model 3345 , England) with a load cell of $500 \mathrm{~N}$. At a crosshead speed of $0.5 \mathrm{~mm} / \mathrm{min}$, tensile load was applied, until bonding failure of the beam occurred [20], [25]. The $\mu$ TBS was calculated in megapascal by a software (Bluehill Lite software, England). 
Table 1: Materials, description, composition, manufacturers, and batch numbers

\begin{tabular}{|c|c|c|c|c|}
\hline Materials & Description & Composition & Manufacturers & $\begin{array}{l}\text { Batch } \\
\text { number }\end{array}$ \\
\hline X-tra fil ${ }^{\circledR}$ & $\begin{array}{l}\text { Packable Bulk-fill resin } \\
\text { composite }\end{array}$ & $\begin{array}{l}\text { Resin matrix: Bis-GMA, UDMA and TEGDMA. Inorganic filler particles: ( } 86 \% \mathrm{w}-70.1 \mathrm{vol} \%) \text { : } \\
\text { Barium alumosilicate glass, fumed silica, and ytterbium fluoride. Photoinitiator: is camphorquinone }\end{array}$ & Voco GmbH & 1612535 \\
\hline X-tra base ${ }^{\circledR}$ & $\begin{array}{l}\text { Flowable Bulk-fill resin } \\
\text { composite }\end{array}$ & $\begin{array}{l}\text { Resin matrix: Is composed of different methacrylate Bis-EMA and aliphatic methacrylate. Inorganic } \\
\text { filler particles: ( } 75 \% \text { w- } 58 \text { vol \%) Barium alumosilicate glass, fumed silica and ytterbium fluoride. } \\
\text { Photoinitiator: is camphorquinone. Amines and butylhydroxytoluene as inhibitor }\end{array}$ & Voco GmbH & 1545476 \\
\hline Grandio $^{\circledR} \mathrm{SO}$ & $\begin{array}{l}\text { Nanohybrid resin } \\
\text { composite }\end{array}$ & $\begin{array}{l}\text { Resin matrix: Based on dimethacrylate, contains Bis-GMA and TEGDMA. Inorganic filler particles: } \\
\text { Nanosized silica filler particles ( } 87 \% \text { w- } 71.4 \mathrm{vol} \%) \text {. BHT (butyle-hydroxy toluene; inhibitor), } \\
\text { camphorquinone (photoinitiator) and color pigments (iron oxide) }\end{array}$ & Voco GmbH & 1608410 \\
\hline Solobond $\mathrm{M}^{\circledast}$ & $\begin{array}{l}\text { Two step, etch and rinse } \\
\text { adhesive system }\end{array}$ & $\begin{array}{l}\text { It is based on: acetone (solvent). It contains HEMA, Bis-GMA, phosphoric acid ester (adhesive } \\
\text { monomer), butylhydroxytoluene (inhibitor) and camphorquinone (photo initiator) }\end{array}$ & Voco GmbH & 1604269 \\
\hline Vococid Gel $^{\circledR}$ & Etchant gel & $\begin{array}{l}\text { Non-dripping gel consistency } \\
34.9 \% \text { phosphoric acid } \\
\text { Blue color for visual control }\end{array}$ & Voco GmbH & 1614279 \\
\hline
\end{tabular}

\section{Statistical analysis}

Data explored for normality using oneway ANOVA and two-way ANOVA test followed by independent $t$-test to detect significance between groups. The significance level was set at $p \leq 0.05$. Statistical analysis was performed with IBM ${ }^{\circledR}$ SPSS $^{\circledR}$ (SPSS Inc., IBM Corporation, NY, USA) Statistics Version 32 for Windows.

\section{Results}

Mean and standard deviation (SD) of $\mu$ TBS values of different $R C$ types in each time were presented in Table 2 and Figure 1. After $24 \mathrm{~h}$, the X-tra base ${ }^{\circledR}$ (C3) showed a highest statistically significant $\mu$ TBS value to dentin $(33.82 \pm 9.84$ megapascal [MPa]) than did the other two types of RC. There was no statistically significant difference between the Grandio $^{\circledR} \mathrm{SO}$ (C1) and the X-tra fil ${ }^{\circledR}$ (C2) $(22.90 \pm 9.51$ $\mathrm{MPa}$ and $27.74 \pm 9.54 \mathrm{MPa}$ ), respectively. After 3 months, Grandio ${ }^{\circledR} \mathrm{SO}$ (C1) showed the highest mean value of $\mu$ TBS to dentin $(18.86 \pm 7.27 \mathrm{MPa})$ followed by the $\mathrm{X}$-tra base ${ }^{\circledR}$ (C3) with no statistically significant difference found between them $(18.86 \pm 7.27 \mathrm{MPa}$ and $15.61 \pm 6.80 \mathrm{MPa}$ ), while the lowest mean value was recorded for X-tra fil ${ }^{\circledR}(\mathrm{C} 2)(10.90 \pm 5.66 \mathrm{MPa})$. Furthermore, a statistically significant change was found between the X-tra $\mathrm{fil}^{\circledR}(\mathrm{C} 2)$ on one hand and

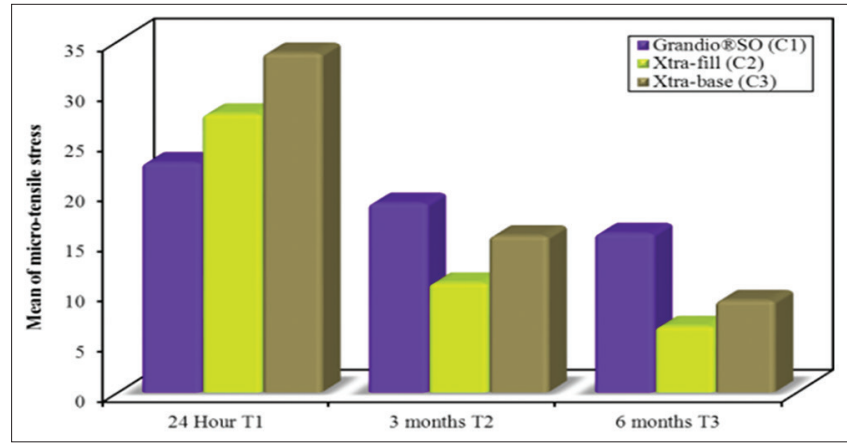

Figure 1: Effect of different resin composite types within each time on microtensile bond strength each of the Grandio ${ }^{\circledR} \mathrm{SO}(\mathrm{C} 1)$ and the X-tra base ${ }^{\circledR}(\mathrm{C} 3)$ on the other hand. After 6 months, the Grandio ${ }^{\circledR} S O$ (C1) showed the highest mean value of $\mu$ TBS to dentin followed by the X-tra base ${ }^{\circledR}$ (C3) $(15.85 \pm 6.76$ $\mathrm{MPa}$ and $9.17 \pm 6.57 \mathrm{MPa}$ ), respectively, while the lowest mean value was reported for the X-tra $\mathrm{fil}^{\circledR}$ (C2) with a mean value $(6.57 \pm 6.38 \mathrm{MPa})$. There was a statistically significant variance in $\mu$ TBS found between Grandio ${ }^{\circledR} \mathrm{SO}$ (C1) and each of X-tra fil ${ }^{\circledR}(\mathrm{C} 2)$ and $X$-tra base ${ }^{\circledR}(C 3)$, while no statistically significant difference was found between the X-tra fil ${ }^{\circledR}(\mathrm{C} 2)$ and the X-tra base ${ }^{\circledR}(\mathrm{C} 3)$.

Overall, concerning the effect of different RC materials on the mean $\mu$ TBS values regardless of the time, X-tra fil ${ }^{\circledR}(\mathrm{C} 2)(15.07 \pm 11.73 \mathrm{MPa})$ showed the lowest mean value of $\mu$ TBS to dentin. There was no statistically significant variance was found between X-tra base ${ }^{\circledR}(\mathrm{C} 3)(19.53 \pm 13.07 \mathrm{MPa})$ and Grandio ${ }^{\circledR}$ SO (C1) $(19.20 \pm 8.37 \mathrm{MPa})$.

Regarding the effect of water storage time on $\mu$ TBS of each RC, there was a statistically significant drop in $\mu$ TBS to dentin was noticed from $24 \mathrm{~h}$ (T1) to 3 months (T2) then to 6 months (T3). A statistically significant difference between the three times of storage was seen in both types of the bulk-fill composite (X-tra $\mathrm{fil}^{\circledR}$ and X-tra base $\left.{ }^{\circledR}\right)$. For the incrementally applied nanohybrid composite (Grandio ${ }^{\circledR} \mathrm{SO}$ ), there was statistically significant difference between the 6 months (T3) and both of $24 \mathrm{~h}$ (T1) and 3 months (T2). While there was no statistically significant difference between $24 \mathrm{~h}$ (T1) and 3 months (T2), as shown in Table 2 and Figure 2.

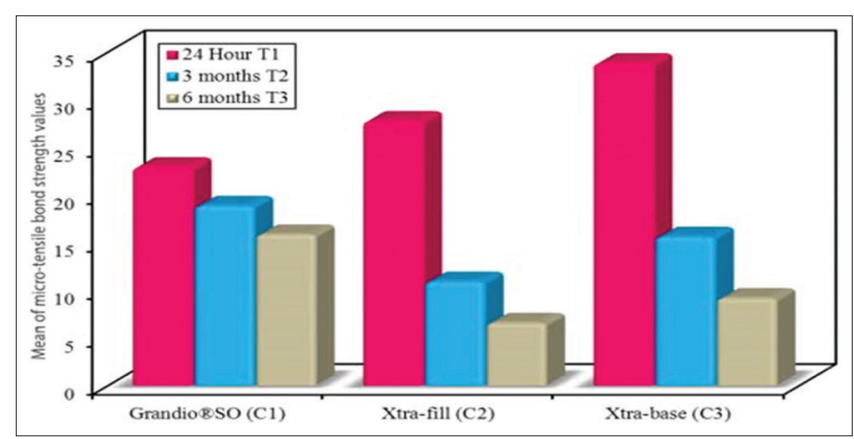

Figure 2: Effect of different times within each resin composite type on microtensile bond strength 
Table 2: The mean and standard deviation of microtensile bond strength values of different resin composite types within each time

\begin{tabular}{|c|c|c|c|c|}
\hline \multirow[t]{3}{*}{ Time } & \multicolumn{3}{|l|}{ Group } & \multirow{3}{*}{$p$ value } \\
\hline & Grandio $^{\circledR} \mathrm{SO}(\mathrm{C} 1)$ & X-tra fil ${ }^{\otimes}(\mathrm{C} 2)$ & X-tra base ${ }^{\circledast}(\mathrm{C} 3)$ & \\
\hline & Mean \pm SD & Mean $\pm S D$ & Mean \pm SD & \\
\hline $24 \mathrm{~h}$ & $22.90 \pm 9.51$ & $27.74 \pm 9.54$ & $33.82 \pm 9.84$ & $<0.001^{*}$ \\
\hline 3 months & $18.86 \pm 7.27$ & $10.90 \pm 5.66$ & $15.61 \pm 6.80$ & $<0.001^{*}$ \\
\hline $\begin{array}{l}6 \text { months } \\
\text { T3 }\end{array}$ & $15.85 \pm 6.76$ & $6.57 \pm 6.38$ & $9.17 \pm 6.57$ & $<0.001^{*}$ \\
\hline$p$ value & $0.004^{*}$ & $<0.001^{*}$ & $<0.001^{*}$ & $\begin{array}{l}<0.001^{*} \\
0.013^{*}\end{array}$ \\
\hline
\end{tabular}

\section{Discussion}

Clinical success of resin-based restorative materials is associated with long-term adhesion success between the restorative material and hard dental tissues [26]. However, reliable adhesion can be compromised by the polymerization contraction stress occurring when composite shrinkage is restricted by adhesion to cavity walls [27]. The sealing of the interfaces is lost when the contraction stress overcomes the bond strength, leading in post-operative sensitivity, marginal staining, and secondary caries [28]. Bond strength assessment in the current study was carried out using $\mu$ TBS as it correlates more accurately with the clinical outcomes than microshear testes [29].

According to storage time, after $24 \mathrm{~h}$ of water storage the results in this study demonstrated that the flowable bulk-fill RC was significantly higher than both of packable bulk-fill RC and the incrementally applied nanohybrid $\mathrm{RC}$. This might be due to the better flowability and the maximum adaptation of the flowable bulk-fill RC to the dentin interface in comparison to the nanohybrid and packable bulk-fill RCs, which are more viscous and of lower wettability. The flowable bulk-fill composite, also characterizing by lower stresses due to its low elastic modulus, compared with the higher modulus of elasticity of nanohybrid and packable bulk-fill RCs [30]. Furthermore, the amount of water sorption and solubility of flowable bulk fill (X-tra base ${ }^{\circledR}$ ) is lower than packable bulk-fill (X-tra fil ${ }^{\circledR}$ ) composite due to the composition of each of them, considering weaker hydrophilic character bis-EMA and UDMA related to the flowable bulk-fill RC in comparison to the bis-GMA of nanohybrid and packable bulk-fill RCs. This fact could be discussed on the grounds that bis-GMA hydroxyl groups created stronger hydrogen bonds with water molecules than the urethane groups that could explain the small water absorption value of the flowable bulk-fill RC [31]. Another explanation for higher bond strength of flowable bulk fill material, that is, X-tra base $^{\circledR}$, probably resulted from lower shrinkage stress due to their content of additives such as pre-polymer stress relievers, polymerization modulators, and modified high molecular weight base monomers [32].

After 3 months of water storage, packable bulk-fill RC exhibited the lowest mean bond strength when compared to the other groups, while no significant difference was found between the flowable bulk fill and the incremental RC. This might be due to the high shrinkage stress generated by the packable bulk-fill composite due to its high modulus of elasticity. It is worth mentioning that composites with high modulus of elasticity produce higher shrinkage stress than do composites with low modulus of elasticity [33]. In general, increasing the fillers load in the resin matrix of packable bulk-fill RC decreases the overall shrinkage of composite resins due to the reduced amount of monomers available for the curing reaction. However, it can also lead to a high elastic modulus of the material that can cause a high shrinkage stress [20], [34], Furthermore, it might be related to the amount of water sorption and water solubility of the three tested RC materials after a period of water storage as discussed before [19].

After 6 months of water storage, the incrementally applied nanohybrid RC showed significantly higher bond strength in comparison to the two bulk-fill RCs. Compared to the incrementally applied RCs, this outcome could be attributed to high polymerization contraction stresses of most bulk-fill RCs [12], [20].

Overall, concerning the effect of different RC materials on the mean $\mu$ TBS values regardless of the time, the results of $\mu$ TBS showed no significant difference between the flowable bulk fill and the incrementally applied nanohybrid RC, while packable bulk-fill composite showed the lowest $\mu$ TBS. Higher filler content is therefore not a higher bond strength indicator [35]. On the other hand, the reason for the differences in $\mu$ TBS results between the incrementally applied nanohybrid RC (Grandio ${ }^{\circledR} S O$ ) and packable bulk fill RC (X-tra fil $\left.^{\circledR}\right)$, despite their similar filler mass fraction (around $85 \%$ ), may be related to the involvement of the other parameters such as particle size, density, type, and ratio of monomers or photoinitiators in both of them [36], [37] This could also be due to the incremental packing technique used with the nanohybrid $\mathrm{RC}$ that providing better polymerization of the RC material [38], [39].

Regarding the effect of storage time on $\mu$ TBS regardless of RC material, the $\mu$ TBS bond strength values adversely affected by time. This could be explained by the biodegradation process of resin-based materials over time, where the daily rate of consumption of aqueous solutions drastically affects the $\mu$ TBS of the resin-based materials [40], [41], [42].

It worth mentioning that there was no significant difference in $\mu$ TBS of nanohybrid RC at $24 \mathrm{~h}$ and 3 months which is not the case for both types of the bulk-fill composite materials. This finding could be attributed to the polymerization contraction stresses of most bulk-fill RCs, which increased over time compared to a conventional RC [12]. This means that contraction stresses of bulk-fill RC increases by time. Furthermore, 
this might be due to the incremental packing technique that was used with the nanohybrid composite as discussed before.

\section{Conclusion}

Within the limitations of the current study, it could be concluded that the packable bulk-fill RC characterized by lower $\mu$ TBS to dentin in comparison to the flowable bulk fill and the incrementally applied nanohybrid RCs. Placing flowable bulk-fill composite (X-tra base) as a base for bulk-fill composite could enhance the $\mu$ TBS of bulk-fill composite to dentin tissue. Furthermore, the $\mu$ TBS of the three tested materials decreased gradually by aging.

\section{References}

1. Moorthy $\mathrm{A}$, Hogg $\mathrm{CH}$, Dowling $\mathrm{AH}$, Grufferty $\mathrm{BF}$, Benetti $\mathrm{AR}$, Fleming GJ. Cuspal deflection and microleakage in premolar teeth restored with bulk-fill flowable resin-based composite base materials. J Dent. 2012;40(6):500-5. https://doi.org/10.1016/j. jdent.2012.02.015

PMid:22390980

2. Rullmann I, Schattenberg A, Marx M, Willershausen B, Ernst CP. Photoelastic determination of polymerization shrinkage stress in low-shrinkage resin composites. Schweiz Monatsschr Zahnmed. 2012;122(4):294-9.

PMid:22513711

3. Roggendorf MJ, Kramer $\mathrm{N}$, Appelt A, Naumann $M$, Frankenberger R. Marginal quality of flowable 4-mm base vs. conventionally layered resin composite. J Dent. 2011;39(10):643-7. https://doi.org/10.1016/j.jdent.2011.07.004 PMid:21801799

4. Rees JS, Jagger DC, Williams DR, Brown G, Duguid W. A reappraisal of the incremental packing technique for light cured resin composites. J Oral Rehabil. 2004;31(1):81-4. https://doi. org/10.1046/j.0305-182x.2003.01073.x

PMid:15125602

5. Xavier JC, Monteiro GQ, Montes MA. Polymerization shrinkage and flexural modulus of flowable dental composites. Mat Res. 2010;13(3):381-4. https://doi.org/10.1590/ s1516-14392010000300017

6. Lazarchik DA, Hammond BD, Sikes CL, Looney SW, Rueggeberg FA. Hardness comparison of bulk-filled/transtooth and incremental-filled/occlusally irradiated resin composites. J Prosthet Dent. 2007;98(2):129-40. https://doi.org/10.1016/ s0022-3913(07)60046-8

PMid:17692594

7. El-Safty S, Silikas N, Watts DC. Creep deformation of restorative resin-composites intended for bulk-fill placement. Dent Mater. 2012;28(8):928-35. https://doi.org/10.1016/j.dental.2012.04.038 PMid:22656273

8. Abbas G, Fleming GJ, Harrington E, Shortall AC, Burke FJ. Cuspal Movement and microleakage in premolar teeth restored with a packable composite cured in bulk or in increments. J Dent. 2003;31(6):437-44. https://doi.org/10.1016/ s0300-5712(02)00121-5

PMid:12878027

9. Leprince JG, Palin WM, Hadis MA, Devaux J, Leloup G. Progress in dimethacrylate based dental composite technology and curing efficiency. Dent Mater. 2013;29:139-56. https://doi. org/10.1016/j.dental.2012.11.005

PMid:23199807

10. Czasch $\mathrm{P}$, llie N. In vitro comparison of mechanical properties and degree of cure of bulk fill composites. Clin Oral Investig. 2013;17:227-35. https://doi.org/10.1007/s00784-012-0702-8 PMid:22411261

11. EL-Damanhoury H, Platt J. Polymerization shrinkage stress kinetics and related properties of bulk-fill resin composites. Oper Dent. 2014;39(4):374-82. https://doi.org/10.2341/13-017-I PMid:23865582

12. Benetti AR, Havndrup-Pedersen C, Honoré D, Pedersen MK, Pallesen U. Bulk fill resin composites: Polymerization contraction, depth of cure, and gap formation. Oper Dent. 2015;40(2):190-200. https://doi.org/10.2341/13-324-I PMid:25216940

13. Unlu N, Gunal S, Ulker M, Ozer F, Blatz MB. Influence of operator experience on in vitro bond strength of dentin adhesives. J Adhes Dent. 2012;14(3):223-7.

PMid:22043471

14. Son SA, Park JK, Seo DG, Ko CC, Kwon YH. How light attenuation and filler content affect the microhardness and polymerization shrinkage and translucency of bulk-fill composites? Clin Oral Investig. 2017;21(2):559-65. https://doi. org/10.1007/s00784-016-1920-2

PMid:27475636

15. Fronza BM, Ayres A, Pacheco RR, Rueggeberg FA, Dias C, Giannini M. Characterization of inorganic filler content, mechanical properties, and light transmission of bulk-fill resin composites. Oper Dent. 2017;42(4):445-55. https://doi. org/10.2341/16-024-I

PMid:28402731

16. Moszner N, Fischer UK, Ganster B, Liska R, Rheinberger V. Benzoyl. Germanium derivatives as novel visible light photoinitiators for dental materials. Dent Mater. 2008;24(7):901-7. https://doi.org/10.1016/j.dental.2007.11.004

PMid: 18155290

17. Van Ende A, De Munck J, Van Landuyt KL, Poitevin A, Peumans M, Van Meerbeek B. Bulk-filling of high C-factor posterior cavities: Effect on adhesion to cavity-bottom dentin. Dent Mater. 2013;29(3):269-77. https://doi.org/10.1016/j.dental.2012.11.002 PMid:23228335

18. Van Ende A, De Munck J, Van Landuyt K, Van Meerbeek B. Effect of bulk-filling on the bonding efficacy in occlusal Class I cavities. J Adhes Dent. 2016;18(2):119-24.

PMid:27042703

19. Juloski J, Carrabba M, Aragoneses JM, Forner L, Vichi A, Ferrari M. Microleakage of Class II restorations and microtensile bond strength to dentin of low-shrinkage composites. Am J Dent. 2013;26(5):271-7. PMid:24479279

20. Al-Harbi F, Kaisarly D, Michna A, ArRejaie A, Bader D, E Gezawi M. Cervical interfacial bonding effectiveness of Class II bulk versus incremental fill resin composite restorations. Oper Dent. 2015;40(6):622-35. https://doi.org/10.2341/14-152-I PMid:26151459

21. Mandava J, Vegesna DP, Ravi R, Boddeda MR, Uppalapati LV, Ghazanfaruddin MD. Microtensile bond strength of bulkfill restorative composites to dentin. J Clin Exp Dent. 
2017;9(8):e1023-8.

\section{PMid:28936294}

22. Syam AN, Gamal S, Sabra MM. Evaluation of micro-tensile bond strength of new composite resins with dentin: An in vitro study. Adv Dent J. 2019;1:37-43. https://doi.org/10.21608/ adjc. 2019.40258

23. Grandi VH, Berger SB, Fugolin AP, Gonini-Júnior A, Lopes MB, Consani $\mathrm{S}$, et al. Microtensile bond strength and microhardness of composite resin restorations using a sonic-resin placement system. Braz Dent J. 2017;28(5):618-23. https://doi. org/10.1590/0103-6440201701469

PMid:29215688

24. Armstrong S, Breschi L, Özcan M, Pfefferkorn F, Ferrari M, Van Meerbeek B. Academy of dental materials guidance on in vitro testing of dental composite bonding effectiveness to dentin/ enamel using micro-tensile bond strength ( $\mu$ TBS) approach. Dent Mater. 2017;33(2):133-43. https://doi.org/10.1016/j. dental.2016.11.015

PMid:28007396

25. Pereira R, Lima DA, Giorgi MC, Marchi GM, AguiarFH. Evaluation of bond strength, nanoleakage, and marginal adaptation of bulkfill composites submitted to thermomechanical aging. J Adhes Dent. 2019;21(3):255-64.

PMid:31165105

26. Manhart J, Chen H, Hamm G, Hickel R. Buonocore memorial lecture. Review of the clinical survival of direct and indirect restorations in posterior teeth of the permanent dentition. Oper Dent. 2004;29(5):481-508. PMid:15470871

27. Braga RR, Ballester RY, Ferracane JL. Factors involved in the development of polymerization shrinkage stress in resin-composites: A systematic review. Dent Mater. 2005;21(10):962-70. https://doi.org/10.1016/j.dental.2005.04.018 PMid: 16085301

28. Carvalho RM, Pereira JC, Yoshiyama M, Pashley DH. A review of polymerization contraction: The influence of stress development versus stress relief. Oper Dent. 1996;21(1):17-24.

PMid:8957911

29. Heintze SD. Clinical relevance of tests on bond strength, microleakage and marginal adaptation. Dent Mater. 2013;29(1):59-84. https://doi.org/10.1016/j.dental.2012.07.158 PMid:22920539

30. Ikeda I, Otsuki M, Sadr A, Nomura T, Kishikawa R, Tagami J. Effect of filler content of flowable composites on resincavity interface. Dent Mater. 2009;28(6):679-85. https://doi. org/10.4012/dmj.28.679

PMid:20019418

31. Alrahlah A, Silikas N, Watts DC. Hygroscopic expansion kinetics of dental resin-composites. Dent Mater. 2014;30(2):143-8. https://doi.org/10.1016/j.dental.2013.10.010

PMid:24268572

32. Tauböck TT, Tarle Z, Marovic D, Attin T. Pre-heating of high-viscosity bulk-fill resin composites: Effects on shrinkage force and monomer conversion. J Dent. 2015;43(11):1358-64. https://doi.org/10.1016/j.jdent.2015.07.014

PMid:26232610

33. Ferracane JL. Developing a more complete understanding of stresses produced in dental composites during polymerization. Dent Mater. 2005;21(1):36-42. https://doi.org/10.1016/j. dental.2004.10.004

PMid: 15681000

34. Ilie N, Bucuta S, Dreaenert M. Bulk-fill resin-based composites: An in vitro assessment of their mechanical performance. Oper Dent. 2013;38:618-25. https://doi.org/10.2341/12-395-I PMid:23570302

35. Behery H, El-Mowafy O, EL-Badrawy W, Saleh B, Nabih S. Cuspal deflection of premolars restored with bulk-fill resin composites. J Esthet Restor Dent. 2016;28:122-30. https://doi. org/10.1111/jerd.12188 PMid:26892364

36. Alshali RZ, Salim NA, Satterthwaite JD, Silikas N. Longterm sorption and solubility of bulk-fill and conventional resin-composites in water and artificial saliva. J Dent. 2015;43(12):1511-8. https://doi.org/10.1016/j.jdent.2015.10.001 PMid:26455541

37. Sagsoz O, Ilday NO, Karatas O, Cayabatmaz M, Parlak H, Olmez MH, et al. The bond strength of highly filled flowable composites placed in two different configuration factors. J Conserv Dent. 2016;19(1):21-5. https://doi.org/10.4103/0972-0707.173188 PMid:26957788

38. Bucuta $\mathrm{S}$, llie N. Light transmittance and micro-mechanical properties of bulk fill vs. conventional resin based composites. Clin Oral Investig. 2014;18(8):1991-2000. https://doi. org/10.1007/s00784-013-1177-y PMid:24414570

39. Leprince JG, Palin WM, Vanacker J, Sabbagh J, Devaux J, Leloup G. Physico-mechanical characteristics of commercially available bulk-fill composites. J Dent. 2014;42(8):993-1000. https://doi.org/10.1016/j.jdent.2014.05.009

PMid:24874951

40. Ahmed HS, Niazy MA, Riad MI, Yaseen AA. In-vivo bond degradation resistance and in-vitro degree of conversion of bulk fill versus nano filled resin composite restoratives. ADJ Girls. 2017;4:33-40. https://doi.org/10.21608/adjg.2017.5193

41. Makishi P, André CB, Ayres A, Martins AL, Giannini M. Effect of storage time on bond strength and nanoleakage expression of universal adhesives bonded to dentin and etched enamel. Oper Dent. 2016;41(3):305-17. https://doi.org/10.2341/15-163-I PMid:26666389

42. Fronza BM, Makishi P, Sadr A, Shimada Y, Sumi Y, Tagami J, et al. Evaluation of bulk-fill systems: microtensile bond strength and non-destructive imaging of marginal adaptation. Braz Oral Res. 2018;32:e80. https://doi.org/10.1590/1807-3107bor-2018. vol32.0080

PMid:30088553 